\title{
Economic performance of processing industries in Pune district of Maharashtra
}

\section{AKSHADA V. KHALADKAR, NEHA A. GODASE AND MAHESH M. KADAM}

Received : 12.06.2017; Revised : 13.09.2017; Accepted : 27.09.2017

\begin{abstract}
Agro-processing is now regarded as the sunrise sector of the Indian economy in view of its large potential for growth and likely socio-economic impact specifically on employment and income generation. Some estimates suggest that in developed countries, upto 14 per cent of the total work force is engaged in agro-processing sector directly or indirectly.People generally prefer fresh fruits and vegetables in India due to abundance of seasonal fruits throughout the year available at low price. The production of pickles and chutneys has traditionally been rural level cottage industrial activity. However, in the recent years, processed foods in the form of canned fruits such as pineapple, Mango slices and pulps, grapes, apple, peaches etc have increased considerably. The uses of fruits in the form of concentrated juice, dry powder, jam and jelly have also increased. The percentage production of processed fruits and vegetables are fruit juice and fruit pulp - 27, jams and jellies - 10, pickles -12, ready to serve beverages -13 , synthetic syrups -8 , squashes -4 , tomato products -4 , canned vegetables- 4 and others -18 .
\end{abstract}

KEY WORDS : Economic performance, Processing industries, Agro-processing, Processed foods

How to cite this paper : Khaladkar, Akshada V., Godase, Neha A. and Kadam, Mahesh M. (2017). Economic performance of processing industries in Pune district of Maharashtra. Internat. J. Com. \& Bus. Manage, 10(2) : 255-260, DOI: 10.15740/HAS/IJCBM/10.2/255260.

NEHA A. GODASE, College of Agribusiness Management, Narayangaon, Pune (M.S.) INDIA

Email: godaseneha212@gmail.com

MAHESH M. KADAM, School of Agriculture, Lovely Professional University, PHAGWARA (PUNJAB) INDIA

Email: mahesh.20181@1pu.co.in 